\title{
Influence of Precursor Concentration and Temperature on the Formation of Nanosilver in Chemical Reduction Method
}

(Pengaruh Kepekatan Pelopor dan Suhu terhadap Pembentukan Nanoargentum dalam Kaedah Pengurangan Kimia)

\author{
N. Ahmad, B.C. ANG*, M.A. Amalina \& C.W. Bong
}

\begin{abstract}
Nanosilver particles (NSPS) were produced by the reduction of silver nitrate using glucose as reducer, poly (vinyl pyrrolidone) as stabilizer and sodium hydroxide as reaction enhancer. Two parameters were investigated which are silver nitrate concentration $(0.1 \mathrm{M}, 0.5 \mathrm{M}$ and $1.0 \mathrm{M})$ and reaction temperature $\left(60^{\circ} \mathrm{C}\right.$ and $\left.80^{\circ} \mathrm{C}\right)$. Through spectral analysis using ultraviolet-visible spectrophotometer (UV-vis), all the samples recorded the maximum peak in the range of 384-411 $\mathrm{nm}$ which verified the formation of NSPS. TEM images showed the nanoparticles have spherical shape with the size range of 25-39 $\mathrm{nm}$. Particle size and zeta potential analysis recorded the hydrodynamic size of nanoparticles in the range of 85-105 $\mathrm{nm}$ and the zeta potential ranging from -25 to $-30 \mathrm{mV}$, under the $\mathrm{pH}$ value of 8 .X-ray diffraction analysis showed that the NSPS have face center cubic (FCC) structure. All the produced NSPs surprisingly showed ferromagneticlike behaviour based on the magnetization curves. FTIR result confirmed the presence of poly (vinyl pyrrolidone) on the NSPS surface. Furthermore, at the reaction temperature $60^{\circ} \mathrm{C}$, the crystallite size, physical size as well as hydrodynamic size increased as the precursor concentration increased from $0.1 \mathrm{M}$ to $0.5 \mathrm{M}$. However, as the precursor concentration further increases to $1.0 \mathrm{M}$, the size become smaller due to incomplete reduction process. In contrast, at $80^{\circ} \mathrm{C}$, the sizes was gradually increased as the precursor concentration increases up to $1.0 \mathrm{M}$. In terms of controlled precursor concentration, the crystallite size and physical size become smaller as the temperature increases.
\end{abstract}

Keywords: Chemical reduction; nanosilver; precursor concentration; reaction temperature

\section{ABSTRAK}

Zarah nanoargentum (NSPS) telah dihasilkan oleh pengurangan argentum nitrat menggunakan glukosa sebagai pengecil, poli (vinil pirolidon) sebagai penstabil dan natrium hidroksida sebagai penggalak tindak balas. Dua parameter yang dikaji merangkumi kepekatan argentum nitrat $(0.1 \mathrm{M}, 0.5 \mathrm{M}$ dan $1.0 \mathrm{M})$ dan suhu tindak balas $\left(60^{\circ} \mathrm{C}\right.$ dan $\left.80^{\circ} \mathrm{C}\right) . \mathrm{Melalui}$ analisis spektrum menggunakan sinar ultra-ungu boleh nampak spektrofotometer (UV-vis), puncak maksimum kesemua sampel direkodkan dalam lingkungan 384-411 nm yang mengesahkan pembentukan NSPS. Imej-imej TEM menunjukkan nanozarah mempunyai bentuk sfera dengan julat saiz 25-39 $\mathrm{nm}$. Analisis saiz zarah dan zeta potential mencatatkan saiz hidrodinamik nanozarah dalam lingkungan 85-105 nm dan zeta potential meliputi -25 hingga -30 mV, di bawah nilai pH 8. Analisis pembelauan sinar-X mendedahkan bahawa NSPS mempunyai struktur face center cubic (FCC). Tanpa dijangka kesemua NSPs yang dihasilkan menunjukkan kelakuan sepertiferomagnetik berdasarkan lengkung pemagnetan. Transformasi Fourier inframerah spektrometer (FTIR) mengesahkan kehadiran poli (vinil pirolidon) di permukaan NSPS. Tambahan pula, pada suhu tindak balas $60^{\circ} \mathrm{C}$, saiz kumin hablur, saiz fizikal serta saiz hidrodinamik meningkat apabila kepekatan pelopor meningkat daripada $0.1 \mathrm{M}$ ke $0.5 \mathrm{M}$. Walau bagaimanapun, apabila kepekatan pelopor terus meningkat kepada 1.0 M, saiz menjadi lebih kecil disebabkan proses pengurangan tidak sempurna. Sebaliknya, di $80^{\circ} \mathrm{C}$, saiz beransur-ansur meningkat apabila kepekatan pelopor meningkat sehingga 1.0 M.Daripada segi kepekatan pelopor yang terkawal, saiz kumin hablur dan saiz fizikal menjadi lebih kecil apabila suhu bertambah.

Kata kunci: Kepekatan pelopor; nanoargentum; pengurangan kimia; suhu tindak balas

\section{INTRODUCTION}

Metal nanostructures especially nanosilver particles (NSPs) have gained enormous attention among researchers and have been exploited in a wide range of applications due to their interesting features such as bactericidal action, improved catalytic activity, unique optical properties, high electrical conductivity ( $\mathrm{Li}$ et al. 2010) and high resistance to oxidation (Nersisyan et al. 2003) as compared to the conventional silver. These NSPs commonly incorporated into products such as purification system (water and air), conductive applications (touch screen and high-intensity LEDs) and optical applications (solar cells and surface plasmonic devices).

Various methods have been developed by the previous researchers in synthesizing NSPs and among the methods, chemical reduction is the most preferable in obtaining 
nanoscale size powders and colloidal dispersion of silver due to simple, convenient operation, ease of control (Lanje et al.2010), systematic and efficient procedure for synthesis without decreasing the production rate (Lah \& Johan 2011) and offers high non-aggregated nanoparticles at low price (Pulit et al. 2011). Even though this method is simple, great care must be exercised to produce a stable and reproducible colloid (Amany et al. 2012; Bell \& Myrick 2001; Šileikaite et al. 2006) and numerous parameters need to be considered because they will influence the properties of nanoparticles particularly particles size. For instance, chemicals used (reducer, stabilizer and accelerator) and reaction conditions (metal salt concentration, temperature and reaction time).

Past researchers reported that strong reducer like borohydride can result in monodispersed small nanoparticles with a faster reduction rate (Ge et al. 2014) but difficult to control the generation of larger particles (Abou El-Nour et al. 2010). In contrast, weaker reducer such as glucose resulted in a slower reduction rate (Abou El-Nour et al. 2010) but displayed better particle uniformity and remarkable antibacterial action (Kheybari et al. 2010; Landage et al. 2014). Wang et al. (2005) obtained well-dispersed spherical NSPs (20-80 nm) by reducing $1.0 \mathrm{M}$ silver nitrate $\left(\mathrm{AgNO}_{3}\right)$ into metallic NSPS in solution containing glucose, poly (vinyl pyrrolidone) (PVP) and sodium hydroxide $(\mathrm{NaOH})$ as reducer, stabilizer and accelerator, respectively at $60^{\circ}$ with 10 min reaction time. In 2010, Lanje et al. has produced spherical NSPS with diameter $15 \mathrm{~nm}$ using same materials with low precursor concentration $(0.01 \mathrm{M})$ and longer reaction time (20 min) at $60^{\circ} \mathrm{C}$. Although, the particles size is smaller but the particles formed cluster. Amany et al. (2012) also synthesized NSPS using glucose but without any stabilizer. They successfully produced spherical and smooth surface NSPs with diameter ranging from $7 \mathrm{~nm}$ to $30 \mathrm{~nm}$ but at the same time, the particles agglomerations can clearly observed through TEM images.

From the above-mentioned studies, it can be concluded that the particles properties, particularly particles size and stability are strongly depending on the precursor concentration, reaction time and even presence of a stabilizer. The agglomeration of particles is still a challenge to the researchers since it is difficult to control. In this paper, the NSPs was produced using the same method as Wang et al. (2005) and Lanje et al. (2010) with some modification by varying the precursor concentration $(0.1 \mathrm{M}, 0.5 \mathrm{M}$ and $1.0 \mathrm{M})$, temperature $\left(60^{\circ} \mathrm{C}\right.$ and $\left.80^{\circ} \mathrm{C}\right)$ and fixing the reaction time to the shortest time. The influence of precursor concentration and temperature on the formation, size and agglomeration of NSPs was checked by a series of characterization. The formation of NSPs was verified using ultraviolet-visible spectrophotometer (UVvis). The size of the nanoparticles was analysed using X-ray diffraction (XRD), transmission electron microscopy (TEM) and zetasizer. Magnetic properties of the nanoparticle were studied using vibrating sample magnetometer (VSM) and the surface chemistry of the nanoparticles was investigated by Fourier transform infrared spectrometer (FTIR).

\section{MATERIALS AND METHODS}

NSPs was obtained by reduction of silver nitrate, $\mathrm{AgNO}_{3}$ (Systerm, China) by $\mathrm{D}(+)$ glucose $\mathrm{C}_{6} \mathrm{H}_{12} \mathrm{O}_{6}$ (R\&M Chemicals, United Kingdom) as reducing agent in the presence of sodium hydroxide pellets, $\mathrm{NaOH}$ (Merck KGaA, Germany) and poly (vinyl pyrrolidone), PVP (Average molecular weight 58,000; Alfa Aesar, Great Britain) as accelerator and stabilizer, respectively. All the analytical grade reactants were used without further purification and prepared in distilled water for the entire experiment.

In this study, two separate solutions were prepared which is solution A and solution B. $270 \mathrm{~mL}$ of solution A containing $106.92 \mathrm{~g} \mathrm{C}_{6} \mathrm{H}_{12} \mathrm{O}_{6}, 17.28 \mathrm{~g} \mathrm{NaOH}$ and $22.86 \mathrm{~g}$ PVPwas heated up to a certain temperature $\left(60^{\circ} \mathrm{C}\right.$ and $\left.80^{\circ} \mathrm{C}\right)$ with continuous stirring for an hour. $90 \mathrm{ml}$ of solution B ( $\mathrm{AgNO}_{3}$ solution) with three different concentration viz $0.1,0.5$ and $1.0 \mathrm{M}$ was added drop by drop into solution $\mathrm{A}$ and once the solution was used up, stirring and the heating process was stopped immediately. The mixture was cooled down to room temperature before centrifugation was carried out at $6000 \mathrm{rpm}$ for $1 \mathrm{~h}$ to separate the particles. The separated particles were washed several times with distilled water until no nitrate ion could be traced and dried at $40^{\circ} \mathrm{C}$ for $24 \mathrm{~h}$ before undergoing a series of characterization test. There were six samples produced with label S1T6, S2T6, S3T6, S1T8, S2T8, and S3T8. S1, S2, and S3 indicating the concentrations of the silver salt precursor which were $0.1 \mathrm{M}, 0.5 \mathrm{M}$, and 1.0 M, respectively. Meanwhile, T6 and $\mathrm{T} 8$ mean the reaction temperature were $60^{\circ} \mathrm{C}$ and $80^{\circ} \mathrm{C}$, respectively. The studied parameters were summarized in Table 1.

TABLE 1. NSPs sample information

\begin{tabular}{ccc}
\hline Sample & $\begin{array}{c}\text { Temperature } \\
\left({ }^{\circ} \mathrm{C}\right)\end{array}$ & $\begin{array}{c}\text { Concentration of } \\
\mathrm{AgNO}_{3}[\mathrm{M}]\end{array}$ \\
\hline S1T6 & & 0.1 \\
S2T6 & 60 & 0.5 \\
S3T6 & & 1.0 \\
S1T8 & & 0.1 \\
S2T8 & 80 & 0.5 \\
S3T8 & & 1.0 \\
\hline
\end{tabular}

Colloidal solution of NSPs were characterized using ultraviolet-visible spectrophotometer (UV-vis), transmission electron microscopy (TEM) and dynamic light scattering (DLS) analysis. The UV-vis absorption spectra was measured within a wavelength range of 300$600 \mathrm{~nm}$ at room temperature by Varian Cary $50 \mathrm{UV}-\mathrm{Vis}$ spectrophotometer. NSPs structure was studied using Leo LIBRA-120 electron microscope operating at $120 \mathrm{kV}$. A drop 
of colloidal solution was placed onto a Lacey formvar/ carbon film supported on a copper grid (ProSciTech Pty Ltd) and evaporated at room temperature. The average size and distribution of NSPs were measured based on a hundred single nanoparticles using Digimizer image analysis software. The hydrodynamic size and the zeta potential of NSPs were measured by dynamic light scattering using Malvern Zeta sizer Nano ZS.

NSPs powder was characterized by X-ray diffractometer (XRD), vibrating-sample magnetometer (VSM) and Fourier transform infrared spectroscopy (FTIR). The crystalline structure of the produced nanoparticles was identified using PANalytical Empyrean XRD with $\mathrm{Cu} \mathrm{K} \alpha$ radiation at $1.5406 \AA$ in a range of $2 \theta=30$ $80^{\circ} \mathrm{C}$ at a scan rate of $0.05 \mathrm{~s}^{-1}$. The crystallite size of the particles was calculated from the obtained diffraction patterns using Scherer's equation (Lanje et al. 2010). Magnetization measurements were carried out using Lake Shore 7400 Series VSM with applied fields of \pm 8000 Oe at room temperature by mounting approximately 17-80 $\mathrm{mg}$ sample into the sample holder. Infrared spectra (IR) with wavenumber range of $4000-500 \mathrm{~cm}^{-1}$ was obtained by using Bruker Tensor 27 and NSPs were ground with potassium bromide (KBr) powder and pressed into platelets beforehand.

\section{RESULTS AND DISCUSSION}

\section{MECHANISM PREDICTION OF NSPS FORMATION}

The first chemical reaction took place in the polymer solution (Solution A) before the addition of $\mathrm{AgNO}_{3}$ solution (Solution B). This reaction was noticed when the color of solution slowly changed to dark brown under constant stirring for 1 hour. Most of the previous researchers reported that glucose directly oxidized to gluconic acid during the synthesis of NSPs (Amany et al. 2012; Darroudi et al. 2010; Wang et al.2005). However, the author believes that the oxidation process of glucose molecules involved two stages. The first oxidation happens in the solution A in which the presence of hydroxide ion $\left(\mathrm{OH}^{-}\right)$caused glucose oxidized to gluconate ion (Figure 1(a)). This oxidation process easily took place due to the presence of a hydrogen atom in aldehyde group (-CHO) which bonded with the carbon-oxygen double bond.

It has been known that dissolving $\mathrm{AgNO}_{3}$ in distilled water did not form any chemical reaction but the molecule dissociated into silver ion $\left(\mathrm{Ag}^{+}\right)$and nitrate ion (NO3-). As soon as the solution $\mathrm{B}$ was introduced into solution $\mathrm{A}$, PVP immediately reacted with $\mathrm{Ag}^{+}$and hydrogen ion $\left(\mathrm{H}^{+}\right)$and generated complex compounds $\left(\mathrm{Ag}-[\mathrm{PVP}]^{+}\right.$and
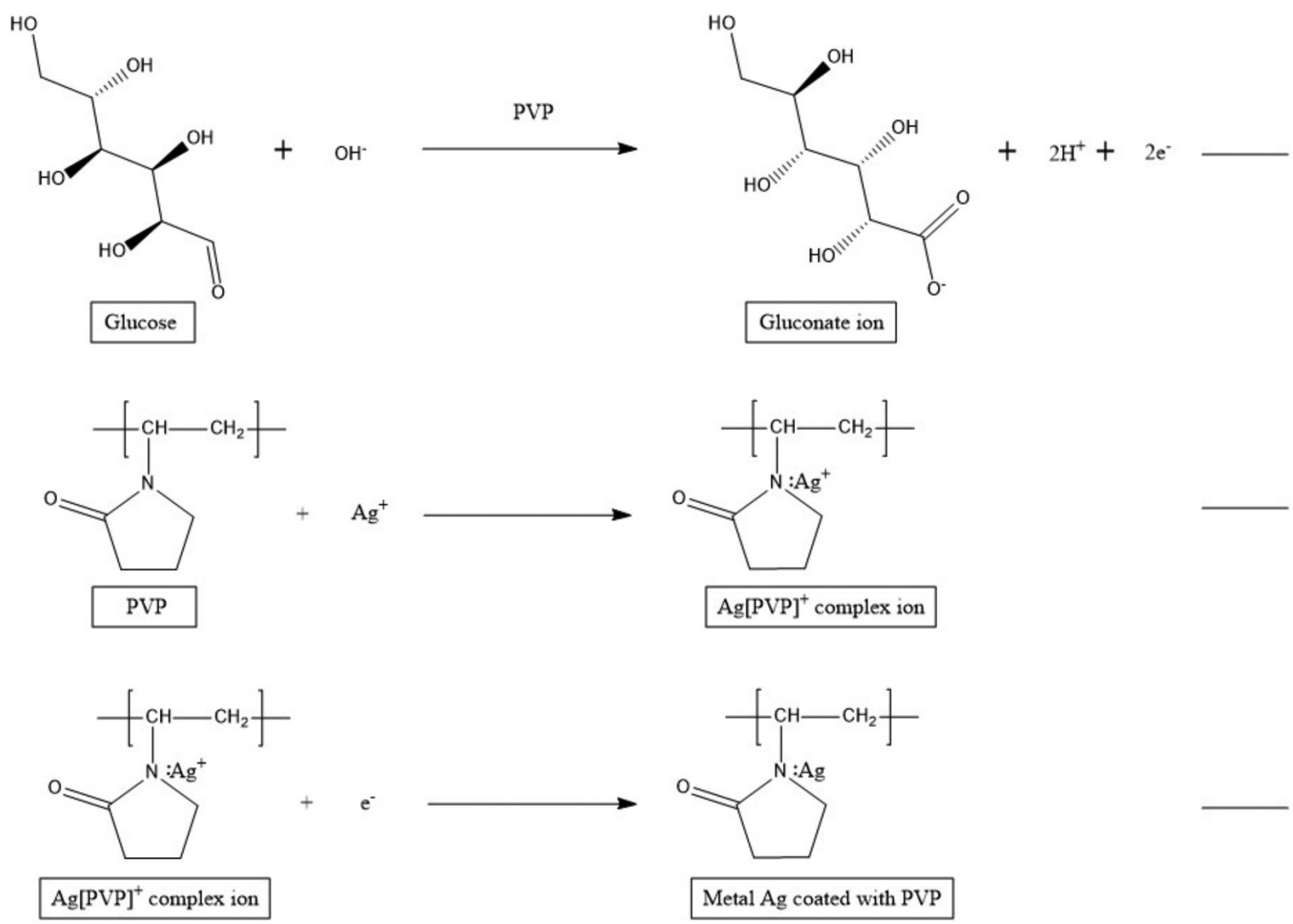

FIGURE 1. (a) Chemical reduction in polymer solution (b) Coordinative bonding between PVP and silver ion (c) Reduction of $\mathrm{Ag}[\mathrm{PVP}]^{+}$complex ion into coated silver metal 
$\left.\mathrm{H}-[\mathrm{PVP}]^{+}\right)$. The formation of the complex compounds especially Ag-[PVP] ${ }^{+}$was observed through the color change from dark brown to black. The stabilization of $\mathrm{Ag}^{+}$ controlled the reaction but the stabilization of $\mathrm{H}^{+}$expedite it (Wang et al. 2005).

According to Zhang et al. (1996), the coordinative complex of $\mathrm{Ag}^{+}$and PVP (Figure 1(b)) are formed when PVP donates lone pair electrons of oxygen and nitrogen atoms to $s p$ orbital of $\mathrm{Ag}^{+}$. PVP promotes the nucleation of metallic silver because $\mathrm{Ag}-[\mathrm{PVP}]^{+}$complex ions are more easily reduced by gluconate ions than pure $\mathrm{Ag}^{+}$due to $\mathrm{Ag}^{+}$receiving more electronic cloud from PVP than from $\mathrm{H}_{2} \mathrm{O}$. During the reduction of $\mathrm{Ag}-[\mathrm{PVP}]^{+}$complex ions to metallic silver (Figure 1(c)), the gluconate ions oxidized to gluconic acid. This generation of complex ions leads to the aggregates of silver atoms which defined as primary nanoparticles by Shin et al. (2004). The primary NSPS combine with each other or interact with PVP and form larger aggregates known as secondary nanoparticles. The overall mechanism of NSPs formation was predicted as illustrated in Figure 2.

\section{OPTICAL ABSORPTION SPECTRA ANALYSIS OF THE NSPS}

Figure 3 shows the UV-Vis spectra of the synthesized NSPS in water. All the NSPs colloidal exhibits strong absorption within a range of $350-460 \mathrm{~nm}$, which is the characteristic absorbance band of the surface plasmon resonance (SPR) for NSPs (Bhui et al. 2009; Lu et al. 2011; Sun et al. 2004; Suwatthanarak et al. 2016). The size of synthesized NSPS was predicted from the spectral based on the shifting of absorption peak and the intensity of the absorbance.

Jiang et al. (2006) reported that the absorption peak will shift to the longer wavelength when the particles become larger. These larger particles tend to form agglomeration or aggregation and cause the surface plasmon resonance shift to lower energy level that lead to the red-shift to longer wavelength due to the delocalize and sharing of conduction electrons near each particle surface among neighboring particles. At $60^{\circ} \mathrm{C}$, the absorbance peak was shifted to longer wavelength as the concentration increases from $0.1 \mathrm{M}$ to $0.5 \mathrm{M}$ and shifted slightly to the shorter wavelength as the concentration further increased to $1.0 \mathrm{M}$, implying the particles size can be predicted as S1T6 < S2T6 > S3T6. A narrow bandwidth with high intensity of S2T6 spectrum was clearly observed which indicates the formation of larger NSPs and increase of number nanoparticles (Suwatthanarak et al. 2016) which will be further verified with TEM image later. For $80^{\circ} \mathrm{C}$ reaction temperature, the particles size become larger as the concentration increases from $0.1 \mathrm{M}$ to $1.0 \mathrm{M}$ as can be seen from the peak shifting phenomena. When the concentration of $\mathrm{AgNO}_{3}$ was increased, the existence of $\mathrm{Ag}^{+}$ions in the system will be higher, so it can promote the growth of NSPs and leading to the formation of larger particles (Jiang et al. 2006).

When the reaction temperature was increased from $60^{\circ} \mathrm{C}$ to $80^{\circ} \mathrm{C}$, the absorbance peak was clearly showed red-shifting (shifting of the peak to the higher wavelength)

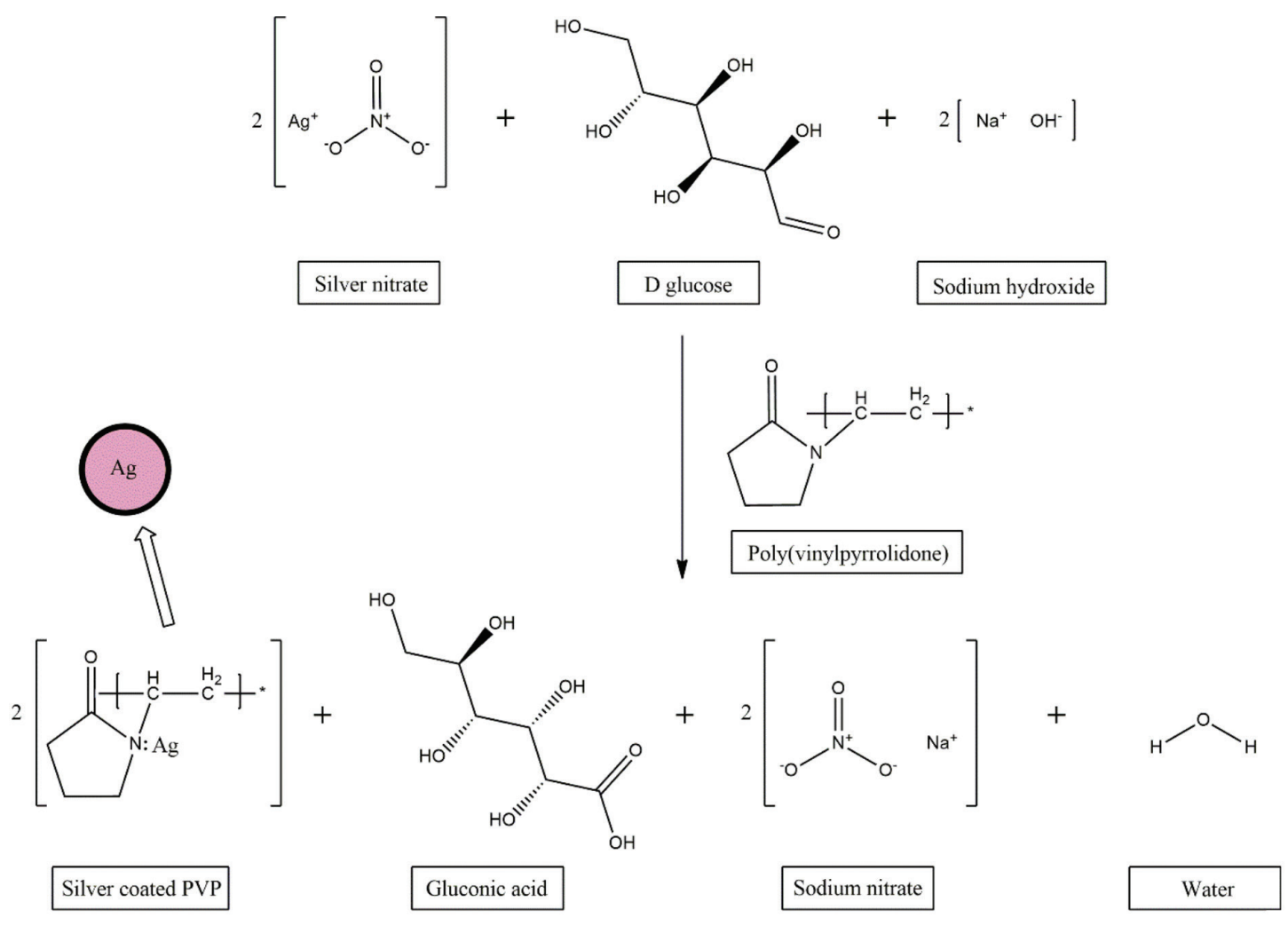

FIGURE 2. The prediction of NSPs formation 


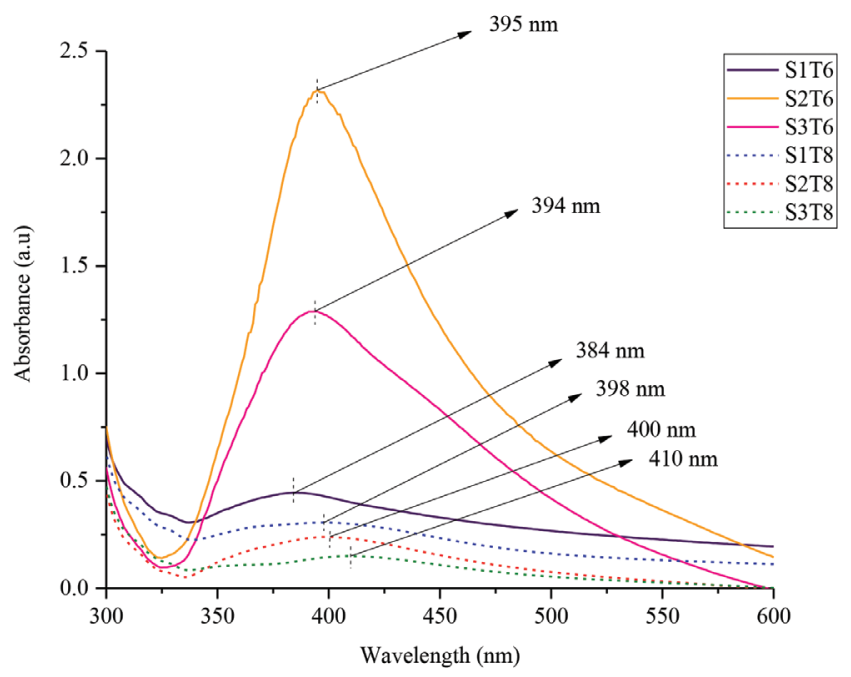

FIGURE 3. The UV-vis spectra of NSPs produced using different $\mathrm{AgNO}_{3}$ concentration $(0.1 \mathrm{M}, 0.5 \mathrm{M}$ and $1.0 \mathrm{M})$ at $60^{\circ} \mathrm{C}$ and $80^{\circ} \mathrm{C}$

for every precursor concentration $(0.1,0.5$ and $1.0 \mathrm{M})$. From this observation, the size of NSPs produced at $60^{\circ} \mathrm{C}$ was predicted smaller than the NSPs synthesized at $80^{\circ} \mathrm{C}$. At low temperature, the formation and growth reaction was slower and in order to complete the reduction, it usually took longer reaction time (Jiang et al. 2011). However, in this study, the reaction was immediately stopped once the dropping process of the precursor was complete. For this reason, the collision frequency may be lower due to low temperature. As a result, the tendency of Ag atoms to bind with each other is lesser and thus, forming smaller nanoparticles. Based on Figure 3, the absorbance intensity of NSPs that produced at high temperature was obviously lower than the synthesized NSPs at $60^{\circ} \mathrm{C}$. The reduction of the absorbance intensity might due to the shrinkage of number of particles or formation of smaller particles.

\section{MICROSCOPIC ANALYSIS ON THE SHAPE AND PHYSICAL SIZE OF NSPs}

Figure 4 shows the TEM images together with the particle distribution for all the produced NSPs using different $\mathrm{AgNO}_{3}$ concentration at $60^{\circ} \mathrm{C}$ and $80^{\circ} \mathrm{C}$, respectively. The figures clearly showed the synthesized nanoparticles were spherical in shape and appear to be a little bit of aggregation. An increment in the number of larger nanoparticles was clearly observed when the concentration increases from $0.1 \mathrm{M}$ to $0.5 \mathrm{M}$ (Figure 4(a) and Figure 4(b)). When the concentration further increased to $1.0 \mathrm{M}$ (Figure 4(c)), the produced NSPS were noticed have smaller size. For the reaction temperature $80^{\circ} \mathrm{C}$, at lower concentration of silver salt precursor (Figure 4(d)), the single spherical nanoparticles still can be observed as compared to Figure 4(e) and Figure 4(f). When the concentration increased to $0.5 \mathrm{M}$, agglomeration obviously took place in the reaction (Figure 4(e)) and further increment of $\mathrm{AgNO}_{3}$ concentration to $1.0 \mathrm{M}$ caused the nanoparticles to aggregate further. According to Lah and Johan (2011),
NSPs begin to aggregate and form larger particles at higher concentration and temperature. At higher concentration of precursor, the agglomeration may be associated with the higher surface energy (Ahmad et al. 2014). Furthermore, the presence of a large amount of precursor created high attraction between atoms (Sibiya \& Moloto 2014), where the Ag atoms tend to attract to each other (Allen et al. 2001) that resulted in the agglomeration and aggregation of nanoparticles.

The physical size distribution of the NSPs was plotted in the box and whisker chart as shown in Figure 5. The black line in the middle of the box indicates the median value of 100 particles and the green line representing the mean value of the size. In both cases, S1T6 and S1T8 have the narrowest size distribution as compared to other samples, where most of the particles lies in the range of $\approx$ $23-31 \mathrm{~nm}$ and $\approx 21-28 \mathrm{~nm}$, respectively. The mean size of NSPs that produced at $60^{\circ} \mathrm{C}$ using $0.1 \mathrm{M}, 0.5 \mathrm{M}$ and $1.0 \mathrm{M}$ was $27.48 \mathrm{~nm}, 35.20 \mathrm{~nm}$ and $25.72 \mathrm{~nm}$, respectively. The calculated mean size of synthesized NSPs at $80^{\circ} \mathrm{C}$ was 25.34 $\mathrm{nm}, 30.79 \mathrm{~nm}$ and $39.13 \mathrm{~nm}$, for S1T8, S2T8 and S3T8, respectively. This calculated size is a good agreement with UV-vis size prediction.

NSPs that prepared using $0.1 \mathrm{M}$ and $0.5 \mathrm{M}$ precursor concentration show a reduction in the physical size as the temperature increases. When the temperature increases, the reaction take shorter time to be completed and nuclei produced have fewer chance to grow into large particles by coagulation (Hee \& Jinki 2007), thus, smaller particles were produced at higher temperature. In addition, an increase in the temperature allowed nanoparticle growth at a faster rate, the reaction for the particle formation may be incomplete in a short duration. Therefore, the observed particle size will be decreased (Zhang et al. 2007). On contrary, when the $\mathrm{AgNO}_{3}$ concentration fixed to $1.0 \mathrm{M}$, the nanoparticles displays an increment in the physical size as the temperature increase. Even though temperature plays a major role in controlling size, the concentration 

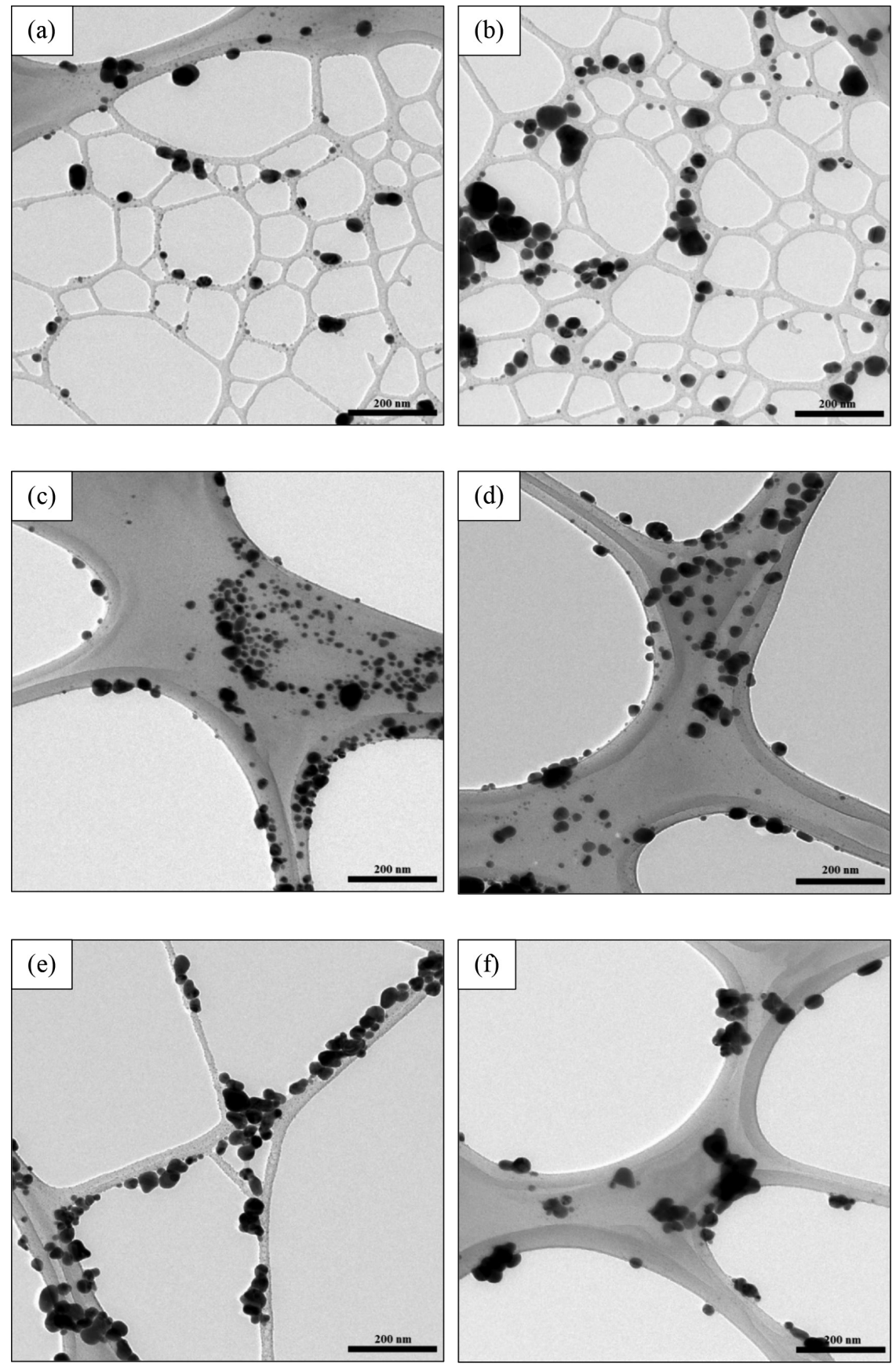

FIGURE 4. TEM image and particles distribution of the synthesized NSPs (a) S1T6 (b) S2T6 (c) S3T6 (d) S1T8 (e) S2T8 and (f) S3T8

of precursor is dominant in this situation. When the concentration of $\mathrm{AgNO}_{3}$ is relatively high, the reducing agent (glucose) might unable to reduce the $\mathrm{Ag}^{+}$completely. As a consequence, the excess $\mathrm{Ag}^{+}$will be deposited on the Ag nuclei that formed in nucleation stage and thus, resulting to the formation of larger NSPS.

\section{PARTICLE SIZE DISTRIBUTION AND ZETA POTENTIAL ANALYSIS OF THE NSP}

Mean hydrodynamic size (Z-average) and zetapotential $(Z p)$ were measured by dynamic light scattering through the correlation function of the scattered intensity (cumulants analysis) and particles mobilities, respectively. Three measurements were taken using automated, optimal measurement times and laser attenuation settings to obtain the average reading for each sample. The average readings for the entire samples were summarized in Table 2.

For both reaction temperature $\left(60^{\circ} \mathrm{C}\right.$ and $\left.80^{\circ} \mathrm{C}\right)$, the mean hydrodynamic sizes were increased as the $\mathrm{AgNO}_{3}$ concentration increases, except the nanoparticles that produced at $60^{\circ} \mathrm{C}$ using $1.0 \mathrm{M}$ of $\mathrm{AgNO}_{3}$. The increasing trend of the NSPs hydrodynamic size is a good agreement with early size forecast by UV-Vis and also physical size from TEM. As the concentration of $\mathrm{AgNO}_{3}$ increases, 


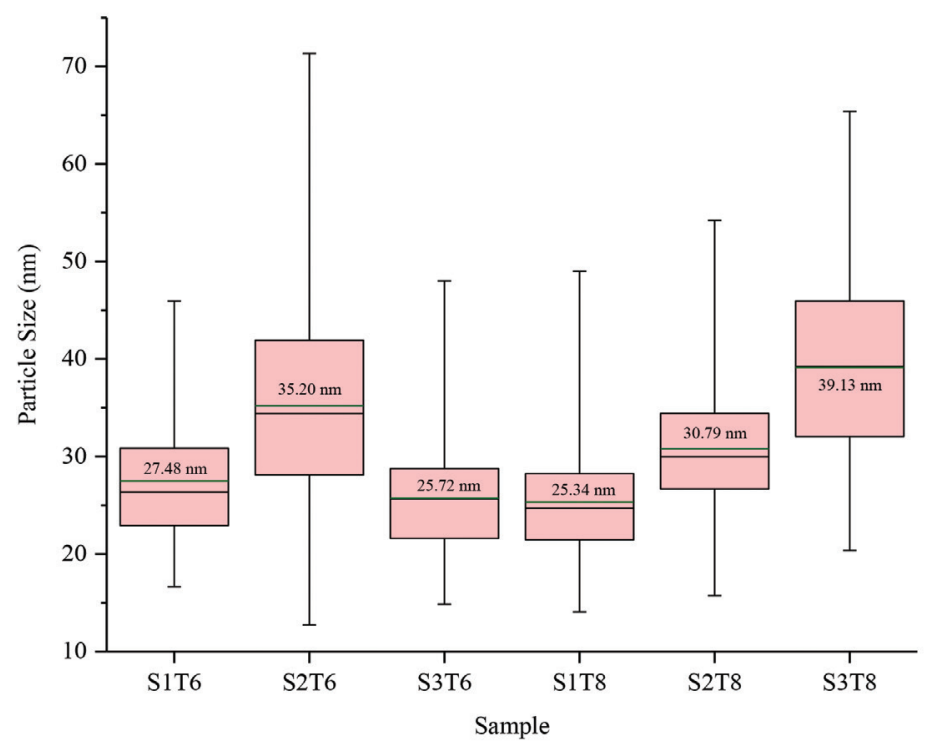

FIGURE 5. Particle size distribution for all samples

TABLE 2 . The average hydrodynamic size, zeta potential, saturation magnetization, coercivity and remanence for all NSPs

\begin{tabular}{cccccc}
\hline Sample & $\begin{array}{c}\text { Hydrodynamic size } \\
(\mathrm{nm})\end{array}$ & $\begin{array}{c}\text { Zeta potential } \\
(\mathrm{mV})\end{array}$ & $\begin{array}{c}\text { Magnetization } \\
(\mathrm{memu} / \mathrm{g})\end{array}$ & $\begin{array}{c}\text { Coercivity } \\
(\mathrm{Oe})\end{array}$ & $\begin{array}{c}\text { Remanence } \\
(\mathrm{memu} / \mathrm{g})\end{array}$ \\
\hline S1T6 & 85.19 & -30.87 & 24.57 & 22.80 & 1.10 \\
S2T6 & 92.98 & -25.17 & 41.63 & 47.88 & 1.92 \\
S3T6 & 64.81 & -30.03 & 1.97 & 18.24 & 1.30 \\
S1T8 & 96.46 & -27.83 & 28.16 & 22.80 & 4.45 \\
S2T8 & 101.0 & -30.37 & 30.75 & 41.04 & 0.0029 \\
S3T8 & 105.2 & -28.47 & 29.90 & 36.48 & 2.12 \\
\hline
\end{tabular}

the hydrodynamic size becomes larger. When $\mathrm{AgNO}_{3}$ concentration is relatively high, the stabilizer might find difficulty to fully coat the particles (Alahmad 2014) and subsequently, increased the fraction of uncoated nanoparticles, leading to higher tendency of the particles to interact with each other (Foliatini et al. 2015). Hence, larger NSPS will be formed. From the view of constant concentration, all the prepared NSPs were demonstrated an increment in the hydrodynamic size as the temperature increases. It has been known that increase in temperature allows higher degree of momentum of moving particles, resulting in higher probabilities of collisions between NSPs by Brownian motion (Chiad et al. 2013), hence causing particles aggregate to form larger particle size.

The zetapotential $(Z p)$ value was measured to estimate the electrostatic stabilization of the nanoparticles. The $Z p$ value was discovered to be in the range from - 25.17 to $-30.87 \mathrm{mV}$ (Table 2). Some of the colloidal NSPs was found have stable dispersion based on the $Z p$ value which was taken at pH8. According to Carneiro-da-Cunha et al. (2011), when the particles have a large positive or negative $Z p$ (greater or lower than $+30 \mathrm{mV}$ and $-30 \mathrm{mV}$ ), they will repel each other and the dispersion is stable. On contrary, when the particles have low $Z p$ values, the particles tend to aggregate due to no sufficient force to prevent the aggregation. Based on this statement, nanosilver colloidal labelled as S1T6, S3T6 and S2T8 can be classified as stable colloidal. The rest colloidal with label S2T6, S1T8 and S3T8 showed lower $Z p$ values, indicating the solution are less stable. These lower $Z p$ values were a good agreement to the TEM images as shown previously, where the particles obviously formed agglomeration and aggregation.

\section{MICROSTRUCTURAL ANALYSIS OF THE NSPS}

The XRD patterns of the synthesized nanoparticles are shown in Figure 6. The prominent peaks were detected at the angle of $2 \theta=38.2^{\circ}, 44.5^{\circ}, 64.6^{\circ}$ and $77.6^{\circ}$ which correspond to the (111), (200), (220) and (311) Bragg's reflections respectively. All the detectable peaks can be indexed to of face-centered cubic (FCC) silver crystal structure which is consistent with the JCPDS 04-0783 (Ajitha et al. 2013). No counterfeit diffraction pattern was observed, indicating the absence of impurities in all the sample. Proving that the produced NSPS was completely pure.

Based on the inset of Figure 6, the intense peak (111) of the produced NSPs at $60^{\circ} \mathrm{C}$ obviously shifted to the higher 


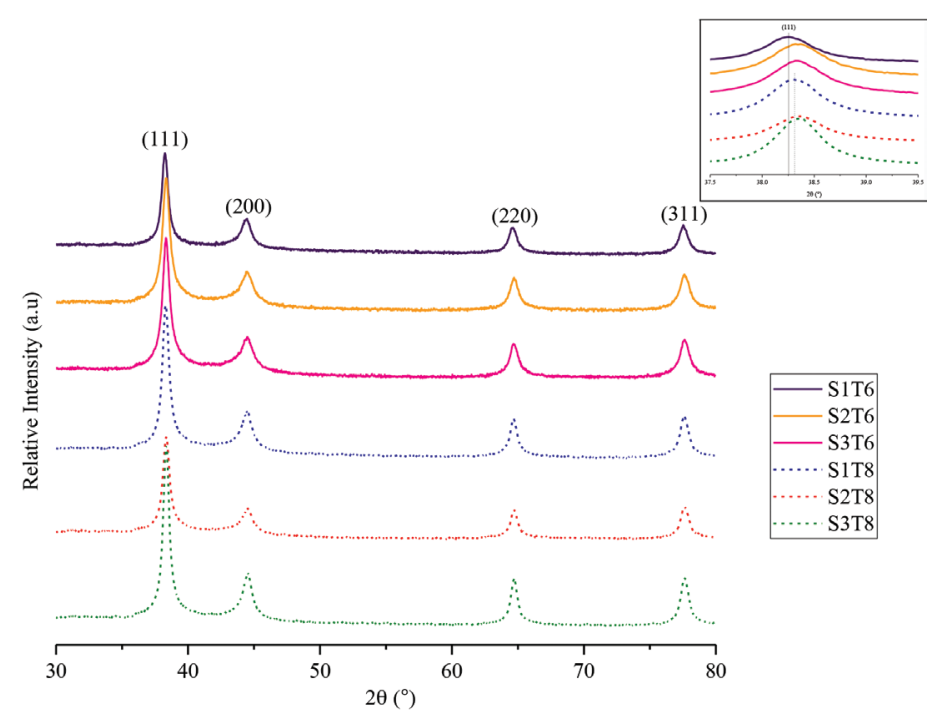

FIGURE 6. XRD patterns of produced NSPs at $60^{\circ} \mathrm{C}$ and $80^{\circ} \mathrm{C}$ for different $\mathrm{AgNO}_{3}$ concentration $(0.1 \mathrm{M}$, $0.5 \mathrm{M}$ and $1.0 \mathrm{M})$. The inset is a magnified view of the shifting of XRD prominent peak at plane (111)

diffraction angle as the precursor concentration increase from $0.1 \mathrm{M}$ to $0.5 \mathrm{M}$ and slightly shifted to the lower angle as the concentration further increase to $1.0 \mathrm{M}$. For the produced NSPS at $80^{\circ} \mathrm{C}$, the peak were slightly shifted to higher angle as the concentration increase from $0.1 \mathrm{M}$ to $1.0 \mathrm{M}$. At constant concentration $(0.1 \mathrm{M}$ and $1.0 \mathrm{M})$, the (111) peak was observed slightly shift to higher angle, while, the intense peak for the produced NSPs using $0.5 \mathrm{M}$ recorded reverse shifting as the temperature increase from $60^{\circ} \mathrm{C}$ to $80^{\circ} \mathrm{C}$. The author believes that these peaks shifting related to the change of lattice causing by the internal stress. When the internal stress increases, lattice tends to shrink which leads the shifting of peak to the higher angle. On contrary, expanded of lattice due to decrease of internal stress will cause the peak to shift to the lower diffraction angle. This peak shifting phenomena was supported by the calculated lattice constant as tabulated in Table 3.

The trend of the diffraction peak intensity and the peak width as shown in Figure 6 was used to predict the pattern of NSPs crystallite size. Hassanien and Akl (2015), reported that an increment of intensity with the reduction of the peak width might due to the crystallite growth, increment of crystallinity degree or both. In order to prove the growth of crystallite, the crystallite size of the NSPS was calculated from the diffraction pattern using Debye-
Scherrer equation (Agnihotri et al. 2014; Ajitha et al. 2013; Lanje et al.2010) and tabulated in Table 3. The calculated size displays similar trend as UV-vis prediction in which the size increased and slightly decreased as concentration increases from $0.1 \mathrm{M}$ to $1.0 \mathrm{M}$ at $60^{\circ} \mathrm{C}$. Same goes to the NSPs that produced at $80^{\circ} \mathrm{C}$ which recorded an increment of crystallite sizes with increasing of precursor concentration. When the concentration increased, the reduction rate increased as well, resulting in an increase of the crystal growth rate on the nuclei that were initially formed, which inhibits further nucleation, concomitantly smaller particles disintegrate and reattach themselves to the larger particles (Choo et al. 2002).

At constant concentration $(0.1 \mathrm{M}$ and $0.5 \mathrm{M})$, the crystallite size of NSPs shows decreasing trend when the temperature increases from $60^{\circ} \mathrm{C}$ to $80^{\circ} \mathrm{C}$. Fayaz et al. (2009) reported that higher temperature will increase the rate of reaction, in which the reactants consume faster, hence reaction depletion takes place, leading to the formation of smaller nanoparticles and narrow size distribution. In contrast, at higher concentration (1.0 M), the crystallite size was found have an increasing trend as the physical size from TEM analysis. The comparison of size between crystallite size, physical size as well as hydrodynamic size was summarized in Figure 7.

TABLE 3. Calculated lattice constant and crystallite size for all samples

\begin{tabular}{cccc}
\hline Sample & $\begin{array}{c}\text { Position }(111) \\
\left({ }^{\circ} 2 \mathrm{Th}\right)\end{array}$ & $\begin{array}{c}\text { Lattice constant } \\
(\AA)\end{array}$ & $\begin{array}{c}\text { Crystallite size } \\
(\mathrm{nm})\end{array}$ \\
\hline S1T6 & 38.24 & 4.073 & 3.30 \\
S2T6 & 38.34 & 4.066 & 5.57 \\
S3T6 & 38.31 & 4.069 & 5.54 \\
S1T8 & 38.27 & 4.071 & 2.53 \\
S2T8 & 38.32 & 4.068 & 3.72 \\
S3T8 & 38.37 & 4.063 & 6.96 \\
\hline
\end{tabular}




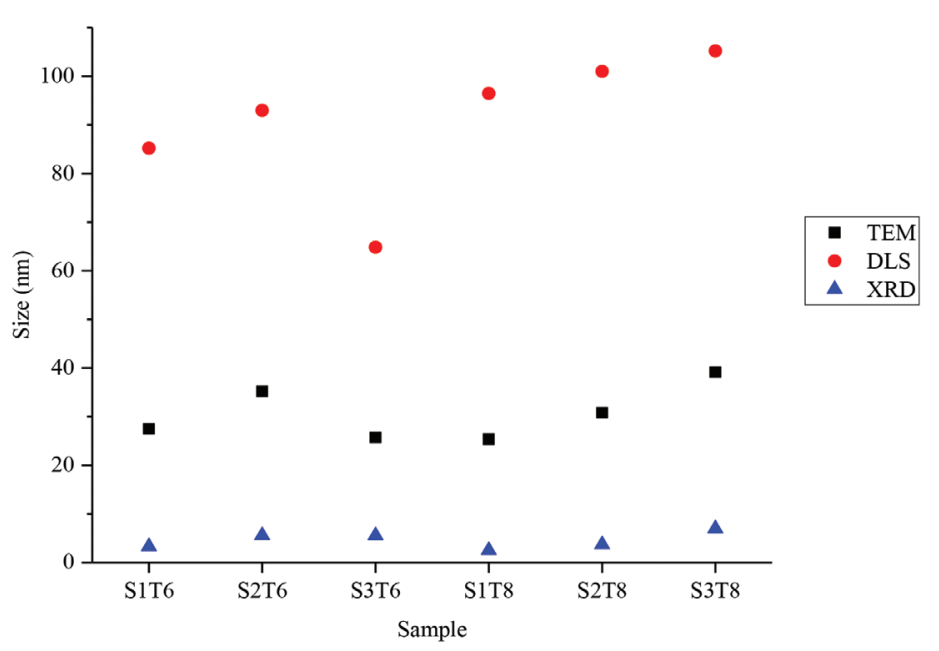

FIGURE 7. Summary of size from TEM, DLS and XRD analysis for all sample

\section{MAGNETIC ANALYSIS OF THE NSPS}

Bulk silver is well known as one of the diamagnetic materials, which shows a negative slope of M-H curve (Jo et al.2006) and produces negative magnetic susceptibility. Surprisingly, silver in nanosize range has different magnetic properties. As shown in Figure 8, the magnetization curve of the produced NSPS shows the non-linear and hysteretic curve. The narrow loops were clearly observed for all the samples as shown in the inset, indicating the ferromagneticlike behaviour of the NSPS. The produced NSPs can be classified as soft magnetic particles due to the shape of the $\mathrm{M}-\mathrm{H}$ curve which have small loop with low coercive forces.

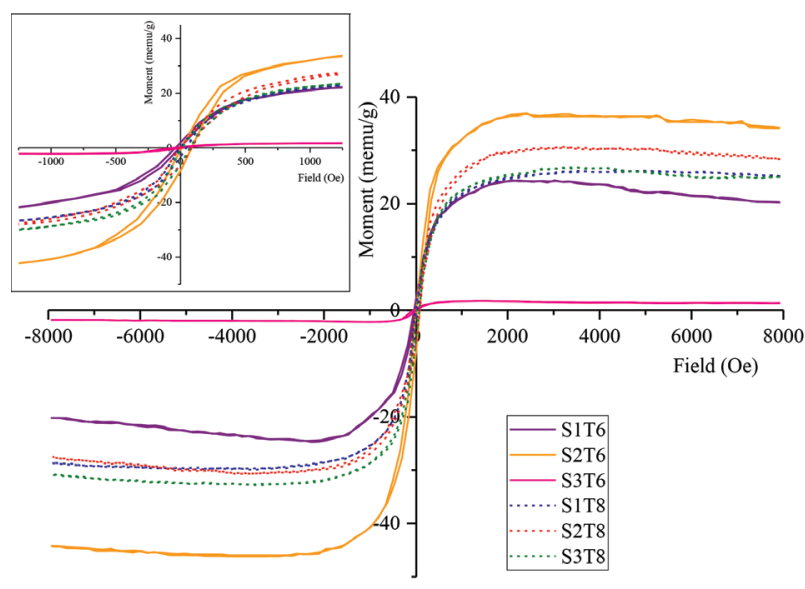

FIGURE 8. Magnetization curves for all samples measured at room temperature. The inset is a magnified view of the curves at low magnetic fields

Table 2 summarizes the value of saturation magnetization $(M s)$, coercivity $(H c)$ and remanence $(M r)$ for all the sample. The changes in the $M s$ and $H c$ show a similar trend for both reaction temperature, which the values increased when the precursor concentration increasing from $0.1 \mathrm{M}$ to $0.5 \mathrm{M}$ and as the concentration further increased to $1.0 \mathrm{M}$, the value shows decrement. This trend has similar pattern as the changes in crystallite size of the prepared NSPs, except for sample S3T8. Generally, the saturation magnetization might related to the size. As reported by Lanje et al. (2010), the reduction in size cause an increment in surface area, leading to higher surface to volume ratio and hence, reduces the saturation magnetization. The inconsistency and randomness of the coercivity and remanence changes might due to the presence of particle aggregations which could influence the magnetic properties of the materials (Eid et al. 2015).

\section{CHEMICAL COMPOSITIONS ANALYSIS OF THE NSPS}

FTIR analysis was performed to detect the presence of PVP on the NSPs surface. Figure 9 demonstrates the FTIR spectra for the synthesized NSPS (S1T8) and pure PVP. All the characteristic peaks of NSPs obviously weaker than the PVP peaks. From the S1T8 spectrum, broad and weak bands were observed at $3433 \mathrm{~cm}^{-1}$ and $2976 \mathrm{~cm}^{-1}$ indicating the stretching vibration of $\mathrm{OH}$ from the intermolecular hydrogen bond and asymmetric $\mathrm{CH}$ from methyl group, respectively. A sharp peak of amide carbonyl group $(-\mathrm{N}-\mathrm{C}=\mathrm{O})$ appeared at $1616 \mathrm{~cm}^{-1}$ was red-shifted from $1648 \mathrm{~cm}^{-1}$ peak in the PVP spectrum. According to Liu et al. (2008) and Zhang et al. (1996), the reduction of wavenumber for the $\mathrm{C}=\mathrm{O}$ band might due to the weakening of bond via partial donation of oxygen to the silver. In the fingerprint region, a sharp and medium absorption band was detected at $1382 \mathrm{~cm}^{-1}$ which might be attributed to the nitrate ions as reported by Janardhanan et al. (2009). At $1253 \mathrm{~cm}^{-1}$ and $1053 \mathrm{~cm}^{-1}$, broad and weak absorption peaks were observed which attribute to -C-N stretching vibration. Both of these peaks were slightly shifted from the PVP peaks. Bryaskova et al. (2011) mentioned in their paper that the peak shifting was related to the formation of coordination bonds between silver atoms and oxygen or nitrogen atoms from PVP units. Basically, the characteristic peaks of PVP were detected in the S1T8 spectrum, indicating that the PVP molecules were adsorbed on the NSPs surface (Liu et al. 2008). 


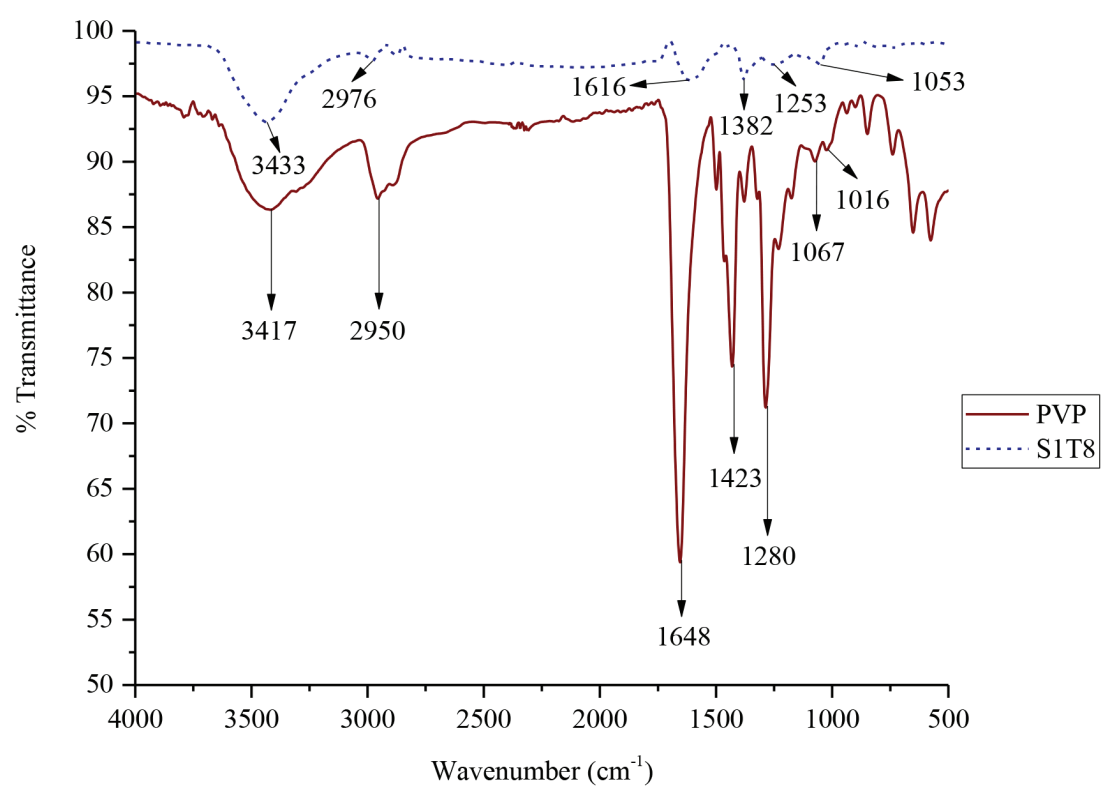

FIGURE 9. FTIR spectra of S1T8 and PVP

\section{CONCLUSION}

In the present work, NSPS are successfully synthesized via chemical reduction method using two different parameters (precursor concentration and synthesis temperature). These synthesis parameters are thoroughly investigated to achieve the optimal condition of NSPs formation. From the results, pure NSPs without any presence of impurities are able to produce using both parameters. The produced NSPS are confirmed coated with PVP based on the presence of PVP functional groups in the NSPs infrared spectrum therefore create a stable suspension with the zeta potential value of $-30 \mathrm{mV}$. The physical size, hydrodynamic size as well as the crystallite size recorded the same trend when the parameter changing either precursor concentration or reaction temperature.

As a conclusion, low precursor concentration with low reaction temperature is the best parameters to produce the smallest size of NSPs (S1T6). By using these parameters, the measured physical, hydrodynamic and crystallite size of the particles are $27.48 \pm 5.22 \mathrm{~nm}, 85.19 \mathrm{~nm}$ and 3.30 $\mathrm{nm}$, respectively. The colloidal S1T6 is classified as a stable solution and they are good in magnetic properties.

\section{ACKNOWLEDGEMENTS}

This research was supported financially by the Universiti Malaya Research Grant (UMRG), RP034C-15AET, Ministry of Education Malaysia under the IOES HiCoE Research Grant (IOES-2014E) and University of Malaya Postgraduate Research Fund (PPP), PG222-2015.

\section{REFERENCES}

Abou El-Nour, K.M.M., Eftaiha, A.A., Al-Warthan, A. \& Ammar, R.A.A. 2010. Synthesis and applications of silver nanoparticles. Arabian Journal of Chemistry 3(3): 135-140.
Agnihotri, S., Mukherji, S. \& Mukherji, S. 2014. Size-controlled silver nanoparticles synthesized over the range 5-100 nm using the same protocol and their antibacterial efficacy. RSC Advances 4(8): 3974-3983.

Ahmad, T., Wani, I.A., Ahmed, J. \& Al-Hartomy, O.A. 2014. Effect of gold ion concentration on size and properties of gold nanoparticles in TritonX-100 based inverse microemulsions. Applied Nanoscience 4(4): 491-498.

Ajitha, B., Divya, A., Harish, G.S. \& Sreedhara, R.D. 2013. The influence of silver precursor concentration on size of silver nanoparticles grown by soft chemical route. Research Journal of Physical Sciences 1(7): 11-14.

Alahmad, A. 2014. Preparation and characterization of silver nanoparticles. International Journal of ChemTech Research 6(1): 450-459.

Allen, E., Henshaw, J. \& Smith, P. 2001. A review of particle agglomeration. U.S. Department of Energy. pp. 1-42.

Amany, A., El-Rab, S.F.G. \& Gad, F. 2012. Effect of reducing and protecting agents on size of silver nanoparticles and their anti-bacterial activity. Der. Pharma. Chemica. 4(1): 53-65.

Bell, W.C.\& Myrick, M.L. 2001. Preparation and characterization of nanoscale silver colloids by two novel synthetic routes. Journal of Colloid and Interface Science 242(2): 300-305.

Bhui, D.K., Bar, H., Sarkar, P., Sahoo, G.P., De, S.P. \& Misra, A. 2009. Synthesis and UV-vis spectroscopic study of silver nanoparticles in aqueous SDS solution. Journal of Molecular Liquids 145(1): 33-37.

Bryaskova, R., Pencheva, D., Nikolov, S. \& Kantardjiev, T. 2011. Synthesis and comparative study on the antimicrobial activity of hybrid materials based on silver nanoparticles (AgNps) stabilized by polyvinylpyrrolidone (PVP). Journal of Chemical Biology 4(4): 185-191.

Carneiro-da-Cunha, M.G., Cerqueira, M.A., Souza, B.W.S., Teixeira, J.A. \& Vicente, A.A. 2011. Influence of concentration, ionic strength and $\mathrm{pH}$ on zeta potential and mean hydrodynamic diameter of edible polysaccharide solutions envisaged for multinanolayered films production. Carbohydrate Polymers 85(3): 522-528. 
Chiad, B., Ali, N., Sadik, Z. \& Al-Awadi, S. 2013. Study the optimum conditions of synthesis AgNP by chemical reduction method. Journal of Kerbala University 11(4): 40-46.

Choo, H.P., Liew, K.Y. \& Liu, H. 2002. Factors affecting the size of polymer stabilized Pd nanoparticles. Journal of Materials Chemistry 12: 934-937.

Darroudi, M., Ahmad, M.B., Abdullah, A.H., Ibrahim, N.A. \& Shameli, K. 2010. Effect of accelerator in green synthesis of silver nanoparticles. International Journal of Molecular Sciences 11(10): 3898-3905.

Eid, C., Assaf, E., Habchi, R., Miele, P. \& Bechelany, M. 2015. Tunable properties of GO-doped $\mathrm{CoFe}_{2} \mathrm{O}_{4}$ nanofibers elaborated by electrospinning. RSC Advances 5: 9784997854.

Fayaz, A., Balaji, K., Kalaichelvan, P. \& Venkatesan, R. 2009. Fungal based synthesis of silver nanoparticles - An effect of temperature on the size of particles. Colloids and Surfaces B: Biointerfaces 74(1): 123-126.

Foliatini, F., Yulizar, Y. \& Hafizah, M.A.E. 2015. The synthesis of alginate-capped silver nanoparticles under microwave irradiation. Journal of Mathematical and Fundamental Sciences 47(1): 31-50.

Ge, L., Li, Q., Wang, M., Ouyang, J., Li, X. \& Xing, M.M.Q. 2014. Nanosilver particles in medical applications: Synthesis, performance, and toxicity. International Journal of Nanomedicine 9: 2399-2407.

Hassanien, A.S. \& Akl, A.A. 2015. Crystal imperfections and Mott parameters of sprayed nanostructure IrO2 thin films. Physica B: Condensed Matter 473: 11-19.

Hee, D.J. \& Jinki, J. 2007. The effects of temperature on particle size in the gas-phase production of $\mathrm{TiO}_{2}$. Aerosol Science and Technology 23(4): 553-560.

Janardhanan, R., Karuppaiah, M., Hebalkar, N. \& Rao, T.N. 2009. Synthesis and surface chemistry of nano silver particles. Polyhedron 28(12): 2522-2530.

Jiang, X., Chen, W., Chen, C., Xiong, S. \& Yu, A. 2011. Role of temperature in the growth of silver nanoparticles through a synergetic reduction approach. Nanoscale Res.Lett. 6(1): 32.

Jiang, H., Moon, K.S., Zhang, Z., Pothukuchi, S. \& Wong, C. 2006. Variable frequency microwave synthesis of silver nanoparticles. Journal of Nanoparticle Research 8(1): 117 124.

Jo, Y., Jung, M.H., Kyum, M.C., Park, K.H. \& Kim, Y.N. 2006. Nano-sized effect on the magnetic properties of Ag clusters. Journal of Magnetics 11(4): 160-163.

Kheybari, S., Samadi, N., Hosseini, S.V., Fazeli, A. \& Fazeli, M.R. 2010. Synthesis and antimicrobial effects of silver nanoparticles produced by chemical reduction method. DARU Journal of Pharmaceutical Sciences 18(3): 168-172.

Lah, N.A.C. \& Johan, M.R. 2011 . Facile shape control synthesis and optical properties of silver nanoparticles stabilized by Daxad 19 surfactant. Applied Surface Science 257(17): 7494-7500.

Landage, S., Wasif, A. \& Dhuppe, P. 2014. Synthesis of nanosilver using chemical reduction methods. International Journal of Advanced Research in Engineering and Applied Sciences 3(5): 14-22.

Lanje, A.S., Sharma, S.J. \& Pode, R.B. 2010. Synthesis of silver nanoparticles: A safer alternative to conventional antimicrobial and antibacterial agents. J.Chem. Pharm. Res. 2(3): 478-483.

Lanje, A.S., Sharma, S.J. \& Pode, R.B. 2010. Magnetic and electrical properties of nickel nanoparticles prepared by hydrazine reduction method. Arch. Phys. Res. 1(1): 49-56.
Li, Z.H., Wang, Y.W. \& Yu, Q.Q. 2010. Significant parameters in the optimization of synthesis of silver nanoparticles by chemical reduction method.Journal of Materials Engineering and Performance 19(2): 252-256.

Liu, H., Zhang, B., Shi, H., Tang, Y., Jiao, K. \& Fu, X. 2008. Hydrothermal synthesis of monodisperse $\mathrm{Ag}_{2} \mathrm{Se}$ nanoparticles in the presence of PVP and KI and their application as oligonucleotide labels. Journal of Materials Chemistry 18: 2573-2580.

Lu, W., Liao, F., Luo, Y., Chang, G. \& Sun, X. 2011. Hydrothermal synthesis of well-stable silver nanoparticles and their application for enzymeless hydrogen peroxide detection. Electrochimica Acta 56(5): 2295-2298.

Nersisyan, H., Lee, J., Son, H., Won, C. \& Maeng, D. 2003. A new and effective chemical reduction method for preparation of nanosized silver powder and colloid dispersion. Materials Research Bulletin 38(6): 949-956.

Pulit, J., Banach, M. \& Kowalski, Z. 2011. Nanosilver making difficult decisions. The International Council on Nanotechnologies 18(2): 185-195.

Shin, H.S., Yang, H.J., Kim, S.B. \& Lee, M.S. 2004. Mechanism of growth of colloidal silver nanoparticles stabilized by polyvinyl pyrrolidone in $\gamma$-irradiated silver nitrate solution. Journal of Colloid and Interface Science 274(1): 89-94.

Sibiya, P. \& Moloto, M. 2014. Effect of precursor concentration and $\mathrm{pH}$ on the shape and size of starch capped silver selenide (Ag2Se) nanoparticles. Chalcogenide Lett. 11: 577-588.

Šileikaitè, A., Prosyčevas, I., Puišo, J., Juraitis, A. \& Guobienè, A. 2006. Analysis of silver nanoparticles produced by chemical reduction of silver salt solution.Mater. Sci.-Medzg. 12: 287-291.

Sun, X., Dong, S. \& Wang, E. 2004. One-step preparation and characterization of poly (propyleneimine) dendrimerprotected silver nanoclusters. Macromolecules 37(19): 7105-7108.

Suwatthanarak, T., Than-ardna, B., Danwanichakul, D. \& Danwanichakul, P. 2016. Synthesis of silver nanoparticles in skim natural rubber latex at room temperature. Materials Letters 168: 31-35.

Wang, H., Qiao, X., Chen, J. \& Ding, S. 2005. Preparation of silver nanoparticles by chemical reduction method. Colloids and Surfaces A: Physicochemical and Engineering Aspects 256(2-3): 111-115

Wang, H., Qiao, X., Chen, J., Wang, X. \& Ding, S. 2005. Mechanisms of PVP in the preparation of silver nanoparticles. Materials Chemistry and Physics 94(2): 449-453.

Zhang, W., Qiao, X. \& Chen, J. 2007. Synthesis of silver nanoparticles-Effects of concerned parameters in water/ oil microemulsion. Materials Science and Engineering: $B$ 142(1): 1-15.

Zhang, Z., Zhao, B. \& Hu, L. 1996. PVP protective mechanism of ultrafine silver powder synthesized by chemical reduction processes. Journal of Solid State Chemistry 121(1): 105-110.

N. Ahmad \& M.A. Amalina

Department of Mechanical Engineering

Faculty of Engineering, University of Malaya

50603, Kuala Lumpur, Federal Territory

Malaysia

B.C.Ang

Center of Advanced Materials 
Department of Chemical Engineering

Faculty of Engineering, University of Malaya

50603, Kuala Lumpur, Federal Territory

Malaysia

\section{C.W. Bong}

Institute of Biological Sciences, (Microbiology Unit)

Faculty of Science, University of Malaya

50603, Kuala Lumpur, Federal Territory

Malaysia
C.W. Bong

Institute of Ocean and Earth Science (IOES)

University of Malaya

50603, Kuala Lumpur, Federal Territory

Malaysia

*Corresponding author; email: amelynang@um.edu.my

Received: 31 December 2016

Accepted: 8 June 2017 